\title{
Language Policy and Decolonizing African Education
}

\author{
Kofi Khepera
}

Decolonizing education in Africa south of the Sahara has been heavily discussed, as the literature indicates (Albaugh, 2009;Owu-Ewie, 2006; Piper \&Miksic, 2011;Sukumane, 1998). A vital component of decolonizing African education is the use of mother tongue languages (Butts \& Haskins, 1973; Wilson, 1987). The NALAP is a language education policy that, in part, encourages the use of Ghanaian mother tongue languages early on in students' education. The Ghanaian government created the NALAP to bolster efforts to decolonize education there (Owu-Ewie, 2006). The following report outlines advocacy actions that can be taken to help decolonize education in Ghana, as well as suggestions ensuring that policies like the NALAP are successfully implemented.

Keywords: language policy, colonization, decolonization, African education, NALAP

\section{INTRODUCTION}

It would seem commonplace today to believe that colonialism was an event, specific only to certain areas of the world. In other instances, colonialism is presented as an outdated event that is "behind us," and is something to be forgotten (Bulhan, 2015). Hussein Bulhan (2015) dealt with the various stages of colonialism: classic colonialism, neocolonialism, and meta-colonialism to explain how to decolonizing psychological science. Bulhan (2015) reported that colonialism, in the classic sense, began in the Americas with the European invasion, occupation, exploitation, and destruction of the native peoples. However, it would seem that colonization in the classic sense that Bulhan (2015) mentioned may have been preceded by that of the Arabs. Uzomah (2018) highlighted the frequently forgotten Arab-Muslim slave trade in and colonization of Africa. For approximately 950 years, an estimated ten million Africans were enslaved and taken from Africa and forced to work in mines as entertainers, and as sex slaves for their slave masters' gratification during the Arab-Muslim trade of enslaved Africans (Austen, 1979; Lovejoy, 2011; Segal, 2001). Using Islam as a vehicle, Arab-Muslim colonizers and slavers were able to inflict serious damage to African culture, traditions, indigenous knowledge, and severely miseducate the Africans they enslaved well before the same type of destruction was caused by Europeans almost a millennia later (Uzomah, 2018). The motivation behind the European exploitation of and savagery toward the people they colonized was more than simply material desires. European self-glorification, to counteract feelings of incompleteness concerning the self, was also motivation for the barbarism displayed during the period of enslavement, colonialism, and post-colonialism in Africa (Bulhan, 2015).

Mosweunyane (2013) pointed out that before the period in African history labeled as colonization, Africans were teaching members of their societies crucial survival skills that were meant to serve the society as a whole. Africans during that period were taught how to physically and spiritually exist within their environments. Part of the legacy of that colonization left behind was the colonizing of the history of 
Africa and its people. In addition to controlling and distorting the history of Africa and African people, Europeans also colonized the channels through which that history was and is currently communicated to Africans and the rest of the world (Mosweunyane, 2013; Rodney, 2018; Wilson, 2014). One such example of the colonization of information about Africa is the prevailing thought that before European invasion and colonization, Africa had no systems of education (Mosweunyane, 2013). Rose Watson (1976) reported on the development of Western education on the continent of Africa. Watson (1976) compared the colonial education systems of the British, French, Belgians, and the Portuguese in their then colonies in Africa south of the Sahara except for the Republic of South Africa. Moreover, Watson (1976) showed, perhaps unintentionally, how African education and culture were being destroyed by Western colonial education systems that were forced upon them.

The decolonization of education for indigenous Black Africans has become and needs to continue being a matter of great discussion and focus in the African scholarly community. Dr. Walter Rodney (n.d.), who was one of the most foremost intellectuals in the Caribbean, wrote How Europe Underdeveloped Africa, which outlines the enslavement, exploitation, and colonization of Africa and Africans by European colonizers. In the section titled Education for Underdevelopment, Rodney (2018) discussed the need for education in Africa and the Diaspora to be decolonized as well as how education can be a catalyst for social change in society. Dr. Rodney (2018) went further and explained that education develops from normal situations; that "education grows out of the environment" (p. 239). Rodney (2018) utilized the example of the Bemba people in the pre-colonial northern area of Zimbabwe. As part of their pre-colonial education, Bemba children were taught to identify as many as fifty to sixty different types of tree plants that were a part of their physical environment without faltering by the age of six. Dr. Rodney (2018) explained that recognition of such plants was a matter of necessity due to being "... in an environment of 'cut and burn' agriculture and in a situation where numerous household needs were met by tree products" (p. 239).

The author will discuss decolonizing education for indigenous Black African children and adolescent students and language education policy in Africa. Specifically, the National Literacy Acceleration Program or NALAP of Ghana will be the language education policy discussed. Using Vygotsky's sociocultural theory, the author will give a brief analysis of the NALAP and the decolonization of child and adolescent education in Ghana. Finally, the author will examine recommendations and best practices for advocacy actions that can help to bring increased awareness to the decolonization of education in Ghana.

\section{LITERATURE REVIEW}

\section{Language Education Policies and Africa - Ghana}

There exists a certain struggle in the work that scholars are publishing and in written policy concerning what medium of instruction is preferred, used, and so on, especially, in Africa south of the Sahara desert (Piper \& Miksic, 2011). There are some groups in parts of Africa south of the Sahara who want English as the medium of instruction, and for what seems like common sense reasons: primary school exams are administered and written in English, and English is seen as a vehicle for economic advancement. Other experts have asserted that children will have an easier time acquiring necessary reading skills in their respective mother tongues (Piper \& Miksic, 2011). With the proper guidance and preparation, educational materials, and other necessary resources to support them, students in Africa south of the Sahara could transmit those foundation skills to English. The transmission of foundation skills would culminate in success with and proficient use of foreign tongues in addition to their mother tongues (Piper \& Miksic, 2011).

Between 1529 and 1925, indigenous languages on the continent of Africa were seen as woefully inadequate as the medium of instruction by the European colonizers. One could argue that language policy in Ghana began with the genesis of 'formal' bilingual education at what was referred to as castle schools. Bilingual education in Ghana like this continued with the arrival of and conversion efforts by the Christian missionaries (Owu-Ewie, 2006). The significance of language education policies and a 
culturally appropriate medium of instruction has been demonstrated by several scholars who have approached the topic of language in education in different ways. Butts and Haskins (1973) (as cited in Wilson, 1987) stated that as children are learning to use a particular language, they also begin the process by which they assimilate the culture system of that language; this includes its meaning, thought processes, and methods of reasoning. Scholars, like Owu-Ewie (2006), have looked at the abandonment of Ghanaian indigenous languages as the medium of instruction and has concluded that such action works in direct opposition to the ideology of their first post-independence leader, Kwame Nkrumah.

Throughout the initial three years of education, Ghanaian students were to be taught in their mother tongues. After some amendments to the NALAP, the program was then supposed to be expanded to all other grade levels across schools in Ghana (Rosekrans, Sherris, \& Chatry-Komarek, 2012). The revival of Ghanaian indigenous languages is considered a move in the direction of decolonizing education in Ghana but the example attempting to be set can also be applied to other African nations seeking to take similar actions. An interesting point about the use of mother tongue languages in education is the perceptions and experiences of the students. Kioko, Ndung'u, Njoroge, and Mutiga (2014) reported that children who are being introduced to education in a foreign language have expressed feelings of frustration. Furthermore, the authors proclaimed "Expecting the child to learn a new language and, at the same time base the development of literacy and other skills on this new language, is simply absurd, and goes contrary to the accepted principles of learning" (p. 3). Kioko, Ndung'u, Njoroge, and Mutiga (2014) declared that mother tongue education has not only educational benefits for the students and the nation but also enhanced economic opportunities.

Ghanaian language education policy underwent various revisions for several reasons, namely the policy previous to the NALAP was being misused. Teachers, according to Owu-Ewie (2006), were not speaking English to the students, which continued as late as the level of sixth-grade elementary school. As a result, Ghanaian students were not demonstrating usage of what was referred to as "good" English, not even upon reaching high school. Ghanaian education, post-independence, was marred by underachievement even with the usage of mother tongues as the medium of instruction at the early grade school levels (Owu-Ewie, 2006). It is argued that Ghanaian children were transitioned to the use of English as the medium of instruction too early, and the transition itself was very sudden. Lewelling (1991) remarked that the degree of proficiency in a first language has an immediate effect on progression in the second language.

\section{Decolonizing African Education for Children and Adolescents}

The language that is used when educating students can have lasting effects. Dr. Cheikh Anta Diop (1987) wrote that opting for a foreign language as the lingua franca, as it has been used in some educational institutions in Africa, can result in the death of national culture. Adika (2012) noted that the English language has shown incredible resilience remaining as the medium of instruction for formal education. Part of the reason for this happening is the language education policies in education that were put in place during the periods of enslavement and colonization. During the period of colonization, for example, schools in Ghana that were using indigenous language(s) as the medium of instruction in their schools did not qualify for any financial support (Adika, 2012). One of the many consequences of the parasitic relationship between Europe and Africa was the development of, among other things, a path to acceptable language and knowledge (Adebisi, 2016). In Ghana today, it would appear much the same with the government there still, for the most part, showing an inability to decide on financial and other resources to adequately promote the use of indigenous languages as the medium of instruction in schools (Adika, 2012).

Decolonizing African education becomes a very difficult undertaking as more and more groups begin to lose the use of their mother tongues (Wilson, 2014). From the perspective of Vygotsky's sociocultural theory, many African countries have listed the languages of their former European colonizers as their official languages (Owu-Ewie, 2006; Sukumane, 1998). Adika (2012) remarked how during the colonization of Africa, European colonizers defunded or underfunded the local schools that utilized their mother tongues as the medium of instruction. In Ghana, the NALAP, which was enacted in 2010, was 
intended to make Ghanaian children literate in two languages; their respective mother tongues and English (Rosekrans, Sherris, \& Chatry-Komarek, 2012). Royer and Carlo (1991) observed that several research studies revealed that a multitude of crucial skills, such as reading comprehension, for example, are transmitted across languages.

Education in several African nations south of the Sahara has been characterized out of context by an insufficient"availability, accessibility, acceptability and adaptability of education" (Adebisi, 2016, p. 433). Certain contextual factors are often not mentioned or considered for a multitude of reasons. As such, the fact that there are educational mismatches present on the continent of Africa leads to ill-equipped citizens and high levels of unemployment and underemployment (Adebisi, 2016; Uzomah, 2018). The educational experience during the period of European colonization was essentially reduced to a tool that allowed for the colonized Africans to communicate with their European masters.

The international bodies involved in education on the continent of Africa have focused the majority of their efforts on 'improving' availability and accessibility of education. The interesting point one must take into account here is that the goals of these international bodies often leave out indigenous Black African knowledge and its role in Africans south of the Sahara receiving a culturally appropriate and relevant education (Adebisi, 2016). Efforts to decolonize education in African south of the Sahara must include reteaching Africans that their mother-tongue languages, philosophies, cultures, and traditions are not prelogical, pre-critical, pre-literate, or in any way inferior to those of the European or Asian civilizations. The final result of, specifically, the European colonization and exploitation of Africa was the muzzling of African history, culture, indigenous knowledge, and self-determination (Rutazibwa, 2014).

\section{THEORY AND SYNTHESIS}

\section{Vygotsky's Sociocultural Theory}

Vygotsky's sociocultural theory focuses on child development as it occurs in a cultural context. The sociocultural theory specifically investigates how the culture of a social group is transferred to subsequent generations (Berk \& Meyers, 2015). Vygotsky's theory states that what he referred to as 'cooperative dialogues' between children and individuals within the social group who are more knowledgeable. It is this social interaction that Vygotsky felt was crucial for the children of a social group in adopting the manners of thinking and behaving that constitute a social group's culture (Berk \& Meyers, 2015). Gauncu and Gauvain (2012) stated a child's participationin informal and formal school settings, home, and community activities with family members, classmates, teachers, in terms of education, are dependent upon the priorities set forth by their particular cultures.

During the period of enslavement and colonialism in Africa, and elsewhere in the African Diaspora, European language and education policies were stifling and stigmatizing the use of African mother tongues, seeking to replace them with English, and other European languages. Hornberger (2008) proclaimed that a shift back toward utilizing a mother-tongue language instruction program. In doing so, it could assist Ghanaians, in this case, in recovering a part of their culture that may have been lost to them during the period of enslavement and colonialism. As Dr. Cheikh Anta Diop (1991) stated, the replacement of a mother tongue by a lingua franca can result in the elimination of a culture. Wilson (1987) and Butts and Haskins (1973) had concluded that for children and adolescents; even adults, acquiring a language also means that the individual is acquiring the methods of thinking and other cultural norms of said language.

If one views the period of enslavement and colonial occupation using Vygotsky's sociocultural theory, it becomes clear how Ghanaian children and adolescents, in particular, developed during this time. According to Vygotsky's theory (2015), a particular group's culture is passed on to the next generation by children who are being taught by more experienced elders or other individuals within the group. Through these social interactions, children are learning ways of thinking and behaving (Berk \& Meyers, 2015; Vygotsky, 1978). However, it is known that duringenslavement and colonialism, the culture of Africans across most of the continent was altered and distorted (Diop, 1991). Now, Ghanaian children and adolescents, for example, have experienced elders and other individuals inculcating distorted versions of 
Ghanaian culture in them, which in turn would most likely be passed on and taught to the next generation (Berk \& Meyers, 2015; Diop, 1991; Vygotsky, 1978). As Göncü and Gauvain (2012) have stated, children and even adolescents are participating in and learning these distorted cultural practices as a result of what transpired during enslavement and colonialism.

\section{ADVOCACY ACTION}

The role that advocacy has played in the success of various movements cannot be overstated. As Nyati-Saleshando (2011) showed in their work, the Wayeyi people of Botswana have advocated for more multicultural education for their children through the Shiyeyi Language Project. The children of the Wayeyi people are to be educated in their mother-tongue language when learning about their culture and traditions. However, these children would then be exposed to the national language(s) of Botswana, and after that, even an international language as the medium of instruction (Nyati-Saleshando, 2011). NyatiSaleshando (2011) also reported that the project is seeing some positive results even in the hostile political and legal environment in which it exists. Continuing such projects are one way that the Wayeyi people are using advocacy to elicit the educational changes they wish to see. Similar advocacy actions are needed in Ghana if one expects changes to the language education policies and the decolonization of African education.

Local languages in Ghana run the risk of being pushed aside for the regular use of colonial European ones (Edu-Buandoh \& Otchere, 2012). Edu-Buandoh and Otchere (2012) analyze the important question of whether Ghanaian students speak English in school due to the choice of a lingua franca, or because of an ideological foundation at work. Their study, they stated, carries implications for the future of the NALAP (Edu-Buandoh \& Otchere, 2012). Ansah (2014) pointed out that an examination of the language policies used throughout Ghana revealed that the Ghanaian government switched from one bilingual policy to another. The frequent switching did not allow for any specific policy to make sufficient progress and was also in some cases, a detriment to the local languages. The work of Göncü and Gauvain (2012) found that a child's involvement in their education, whether they are involved in: informal, formal, home, school, and community activities, are in large part reliant upon the cultural priorities of their respective cultural groups. Children will often take part in these activities with teachers, family members, and peers.

The Wayeyi people of Botswana engaged in community outreach to raise awareness about the importance of their children receiving their early education in their mother tongue but also receiving a multilingual education after that (Nyati-Saleshando, 2011). Those advocating for decolonizing language education policies in Ghana can partner with others there who may be currently engaged in or seeking to assist in advocacy efforts. Another recommended approach to advocacy action used by the Wayeyi people is contacting a government representative. Similarly to the Wayeyi people, those advocating for decolonizing language education policies in Ghana can request to meet with a Ghanaian government representative whose constituents are affected by the NALAP. Contacting a government representative can lead to discussions about ways to be involved in the efforts in Ghana to decolonize education (NyatiSaleshando, 2011). As Nyati-Saleshando (2011) stated, the Shiyeyi Language Project (SLP) was able to successfully engage in advocacy actions to save the Shiyeyi language from extinction by presenting the project to the Wayeyi community to own it, and to the global community to raise awareness about it.

\section{Contact Government Representative}

There are members of the Ghanaian government who are current members of the WhatsApp group, the Wellness Communiversity. By contacting a government representative whose constituents may be affected by the NALAP policy, individuals can engage them in discussion to determine how they can get involved in outreach initiatives in Ghana. Having discussions with a Ghanaian government representative is yet another way to obtain necessary information about the NALAP. Researchers and advocates can learn how they perceive the NALAP's effectiveness in the decolonization of African education not just in Ghana but how similar policies would be effective elsewhere on the continent. Aside from working 
toward the decolonization of African education, developing a plan to successfully implement ideas or changes is another potential goal to work toward achieving.

The literature has shown that the most consistently mentioned obstacle to utilizing language education policies to be the implementation of the policies and ideas (Ansah \& Agyeman, 2015; EduBuandoh \& Otchere, 2012). Discussing such matters with government representatives will hopefully accomplish a multitude of objectives. The first of which is, to uncover reasons for the failed implementation of policies and ideas like the NALAP. Moreover, firsthand accounts can be obtained from representatives about the entrenched position of the English language in the lives of Ghanaians (EduBuandoh \& Otchere, 2012).

There may be times when those looking to talk to government representatives are not located in Ghana itself, and as a result, will not have easy access to Ghanaian government officials. To try and mitigate the challenge of not being on-site in Ghana, WhatsApp can be utilized in an attempt to reach out to Ghanaian government officials. There is a WhatsApp group that exists called the Wellness Communiversity. The Wellness Communiversity was founded and is managed by Dr. Carnita Groves and is a Pan-African and African-centered platform where its members engage in regular discussions about matters concerning the African continent, especially matters relevant to the Ghanaian society. There are upwards of 250 plus members on the platform; many of which are professionals in several different fields of study, including politics (Groves, 2020). There are still challenges associated with attempting to contact a government spokesperson via WhatsApp, such as whether or not the official a person is trying to contact uses WhatsApp.

\section{Performing Community Outreach}

Through the Wellness Communiversity platform, the researchers and advocates can partner with other education professionals in Ghana to discuss engaging in community outreach. Such engagement can result in a movement for change being developed; a movement that could generate change within the Ghanaian education system (Rosekrans, Sherris, \& Komarek, 2012). Additional steps that can be taken via WhatsApp and the Wellness Communiversity platform are the creation of other platforms. Platforms dedicated to advocating for decolonizing African education and language education policies in one example of such steps. One of several challenges one may encounter performing community outreach is ensuring that the thoughts and opinions of those that represent the groups affected by the NALAP in Ghana are being collected (Australian Institute of Family Studies, 2019). If the students in the Ghanaian education system are to benefit in any way from the decolonization of their education and language education policies, there must be meaningful and purposeful interaction between them and government representatives, community leaders, researchers, and so forth (Australian Institute of Family Studies, 2019). Researchers and advocates will need to ensure that they ask people affected by NALAP about their aspirations, values, and concerns; thus, using that information in the decision-making process (Australian Institute of Family Studies, 2019). By performing community outreach, individuals can work toward strengthening the national consciousness and provide a strong foundation for implementing language education policies like the NALAP (Nyati-Saleshando, 2011).

\section{RECOMMENDATIONS AND BEST PRACTICES}

As previously stated, there are members of the Ghanaian government who are current members of the Wellness Communiversity platform. By contacting a government representative whose constituents may be affected by the NALAP policy, researchers may inquire about participating in discussions to determine how to get involved in outreach initiatives in Ghana. Discussions with Ghanaian government representatives are also an excellent way to obtain necessary information about policies like the NALAP as well as to understand how they perceive its effectiveness in the effort to decolonize African education. Another goal is developing a plan to successfully implement ideas or changes. The literature has shown that the most consistently mentioned obstacle to utilizing the language education policies and end up helping to decolonize African education is the implementation of the policies and ideas (Ansah \& 
Agyeman, 2015; Edu-Buandoh\&Otchere, 2012). Discussing such matters with government representatives will hopefully accomplish several objectives. The first of which is, to uncover reasons for the failure to implement policies and ideas like the NALAP in the past. Moreover, firsthand accounts can be obtained from government officials about the entrenched position that English has taken in the lives of Ghanaians (Edu-Buandoh\&Otchere, 2012).

It may not always be possible for researchers and advocates to be on-site in Ghana. Thus, they will not have access to having discussions in person with government representatives. To mitigate the challenges of not being on-site in Ghana, researchers and advocates can attempt to reach out to Ghanaian government officials via WhatsApp. Utilizing WhatsApp for video calling can be an effective alternative to face to face discussions. Using WhatsApp is not without its challenges as well. One of the possible challenges is that the government officials that a person tries to reach may not have a WhatsApp account.

Albaugh (2009) observed that advocacy efforts to implement mother-tongue languages as the medium of instruction in Francophone African nations received support from a network of French academics in Belgium, France, Canada, and Africa. Furthermore, Albaugh's (2009) assessment of Anglophone countries Africa appears correct. It revealed that the leaders of these nations often were given contradictory guidance and advice. As a result, Anglophone countries in Africa have had trouble creating and implementing policies that aid in decolonizing education and prioritizing the usage of mother tongue languages in their education systems. The inconsistencies found among scholars and the leaders of the Anglophone African countries highlights the potential lack of unity and consensus necessary for implementing policies like the NALAP (Albaugh, 2009).

It is recommended that educators in Ghana, beginning discussing implementation of the NALAP at the local level. The NALAP should be implemented in all schools to encourage consistency in the languages the students are using. As Piper and Miksic (2011) further explained, it gives the students the chance to utilize the language skills that they are learning in the home at school. Moreover, students who are learning in the same language that is used at home are likely to acquire proper reading skills rather than those students who are being taught in English (Piper \&Miksic, 2011).

\section{CONCLUSION}

The literature has shown that language education policy has remained a heavily discussed topic since the period of colonization in Africa (Albaugh, 2009; Owu-Ewie, 2006; Piper \&Miksic, 2011; Sukumane, 1998). The use of a language, more specifically, a mother tongue language when educating students, can have a sustained influence on a child's education (Wilson, 1987, 2014). Göncü and Gauvain (2012) discussed decolonizing education in Africa and revealed the importance of undertaking such an endeavor. The authors proclaimed that without sustained efforts to remove the influence of European colonial rule on the education systems of Africa, African children and adolescents will continue to learn in distorted cultural environments and practice distorted cultural traditions due in part to what transpired during enslavement and colonialism (Göncü\&Gauvain, 2012).

The literature has also shown that one of the hurdles preventing the enforcement of language education policies and ideas is implementation (Ansah \& Agyeman, 2015; Edu-Buandoh\&Otchere, 2012). Speaking to government representatives about these matters could serve to accomplish multiple goals. The first of which is to highlight implementation failure and feasible approaches to address and overcome those failures. Language has been shown to play a significant role in the decolonization process. Scholars like Ouane and Glanz (2010) have shown the importance of the connections between language and the practicing of certain traditions and aspects of one's culture. 


\section{REFERENCES}

Adebisi, F. I. (2016). Decolonising education in Africa: Implementing the right to education by reappropriating culture and indigeneity. N. Ir. Legal Q., 67, 433.Retrieved from https://nilq.qub.ac.uk/index.php/nilq

Adika, G. S. K. (2012). English in Ghana: Growth, tensions, and trends. International Journal of Language, Translation and Intercultural Communication, 1, 151-166.doi:10.12681/ijltic.17

Albaugh, E. A. (2009). The colonial image reversed: Language preferences and policy outcomes in African education. International Studies Quarterly, 53(2), 389-420.doi:10.1111/j.14682478.2009.00539.x

Ansah, M. A., \& Agyeman, N. A. (2015). Ghana language-in-education policy: the survival of two south Guan minority dialects. Per Linguam: Journal of Language Learning= Per Linguam: TydskrifvirTaalaanleer, 31(1), 89-104.doi:10.5785/31-1-592

Austen, R. A. (1979). The Trans-Saharan slave trade: A tentative census. In H. A. Gemery \& J. S. Hogendorn (Eds.), The uncommon market: Essays in the economic history of the Atlantic slave trade. New York, NY: Academic Press.

Australian Institute of Family Studies. (2019). Community Engagement. Retrieved from https://aifs.gov.au/cfca/publications/community-engagement/introduction.

Berk, L. E., \& Meyers, A. B. (2016). Infants, children, and adolescents (8th ed.). Boston, MA: Pearson.

Bulhan, H. A. (2015). Stages of colonialism in Africa: From occupation of land to occupation of being. Journal of Social and Political Psychology, 3(1), 239-256. doi:10.5964/jspp.v3i1.143

Butts, H. F., \& Haskins, J. (1973). The psychology of Black language. New York, NY: Barnes and Noble Books.

Diop, C. A. (1987). Black Africa: The economic and cultural basis for a federated state. Chicago, IL: Chicago Review Press.

Diop, C. A. (1991). Civilization or barbarism. Chicago, IL: Chicago Review Press

Edu-Buandoh, D. F., \& Otchere, G. (2012). "Speak English!" A prescription or choice of English as a lingua franca in Ghanaian schools. Linguistics and Education, 23(3), 301-309. doi:10.1016/j.linged.2012.06.003

Göncü, A., \&Gauvain, M. (2012). Sociocultural approaches to educational psychology: Theory, research, and application. In K.R. Harris, S. Graham, T. Urdan, C. B. McCormick, G. M. Sinatra, \& J. Sweller (Eds.), APA educational psychology handbook. Theories, constructs, and critical issues (vol. 1, pp. 125-154). doi.org/10.1037/13273-006

Groves, C. M. (2020). Wellness Communiversity. Retrieved from https://www.wellnesscommuniversitygh.org/

Hornberger, N. H. (2008). Voices and biliteracy in indigenous language revitalization. In K.A. King, N. Schilling-Estes, J.J. Lou, L. Fogle, \& B. Soukup (Eds.), Sustaining linguistic diversity (pp. 95109). Washington, DC: Georgetown University.

Kioko, A. N., Ndung'u, R. W., Njoroge, M. C., \& Mutiga, J. (2014). Mother tongue and education in Africa: Publicising the reality. Multilingual Education, 4(1), 1-11. doi:10.1186/s13616-014-0018$\mathrm{X}$

Lewelling, V. W. (1991). Academic Achievement in a Second Language. ERIC Digest. Retrieved from ERIC database. (ED329130)

Lovejoy, P. E. (2011). Transformations in slavery: A history of slavery in Africa (3rd ed.). New York, NY: Cambridge University Press.

Mosweunyane, D. (2013). The African educational evolution: From traditional training to formal education. Higher Education Studies, 3(4). doi:10.5539/hes.v3n4p50

Nyati-Saleshando, L. (2011). An advocacy project for multicultural education: The case of the shiyeyi language in botswana. International Review of Education /

InternationaleZeitschriftFürErziehungswissenschaft / Revue Internationale De l'Education, 57(5/6), 567-582. doi:10.1007/s11159-011-9254-4 
Ouane, A., \& Glanz, C. (2010). How and why Africa should invest in African languages and multilingual education. Hamburg, Germany: UNESCO Institute for Lifelong Learning

Owu-Ewie, C. (2006). The language policy of education in Ghana: A critical look at the English-only language policy of education. In Selected proceedings of the 35th annual conference on African linguistics (pp. 76-85). Somerville, MA: Cascadilla Proceedings Project.

Piper, B., \& Miksic, E. (2011). Mother tongue and reading: Using early grade reading assessments to investigate language of instruction policy in East Africa. In A. Gove \& A. Wetterberg (Eds.), The early grade reading assessment: Applications and interventions to improve early grade literacy. RTI Press

Rodney, W. (2018). How Europe underdeveloped Africa (New ed.). La Vergne, TN: Verso.

Rosekrans, K., Sherris, A., \& Chatry-Komarek, M. (2012). Education reform for the expansion of mothertongue education in Ghana. International Review of Education, 58(5), 593-618. doi:10.1007/s11159-012-9312-6

Rutazibwa, O. U. (2014). Studying Agaciro: Moving beyond Wilsonian interventionist knowledge production on Rwanda. Journal of Intervention and Statebuilding, 8(4), 291302.doi:10.1080/17502977.2014.964454

Segal, R. (2001). Islam's Black slaves: The other Black Diaspora. New York, NY: Farrar, Straus and Giroux

Sukumane, J. B. G. (1998). African languages, English, and educational policy in Namibia. Studies in the Linguistic Sciences, 28(1), 207. Retrieved from https://www.ideals.illinois.edu/handle/2142/11557

Uzomah, H. O. (2018). Decolonizing African educational system as a panacea for Africa's educational advancement in the 21 st century. African Renaissance, 15(1), 29-43. Retrieved from https://journals.co.za/content/journal/aa_afren

Vygotsky, L. S. (1978). Mind in society: The development of higher psychological processes. Cambridge, UK: Harvard University Press.

Walter Rodney Foundation. (n.d.). Walter Rodney \& Works | The Walter Rodney Foundation. Retrieved from https://www.walterrodneyfoundation.org/biography/

Watson, R. T. (1976). African Educational Systems: A Comparative Approach.Edu 510. Retrieved from ERIC database. (ED125949)

Wilson, A. N. (1987). The developmental psychology of the Black child. New York, NY: Africana Research Publications.

Wilson, A. N. (2014). The falsification of Afrikan consciousness: Eurocentric history, psychiatry and the politics of White supremacy (2nd ed.). New York, NY: Afrikan World InfoSystems. 